\title{
Woody Species Richness and Diversity at Ades Dry Afromontane Forest of South Eastern Ethiopia
}

\author{
Muktar Reshad*, Alemayehu Beyene, Muktar Mohammed \\ College of Natural Resource and Environmental Science, Oda Bultum University, Chiro, Ethiopia \\ Email address: \\ r1muk@yahoo.com (M. Reshad) \\ ${ }^{*}$ Corresponding author
}

To cite this article:

Muktar Reshad, Alemayehu Beyene, Muktar Mohammed. Woody Species Richness and Diversity at Ades Dry Afromontane Forest of South Eastern Ethiopia. American Journal of Agriculture and Forestry. Vol. 7, No. 2, 2019, pp. 44-52. doi: 10.11648/j.ajaf.20190702.12

Received: January 12, 2019; Accepted: March 22, 2019; Published: April 18, 2019

\begin{abstract}
The study was conducted at Ades Dry Afromontane Forest at $407 \mathrm{~km}$ Southeast of Addis Ababa to assess the diversity and composition of woody plant species. The sampling design was based on a US Forest Service model for the indigenous forests. A total of 60 circular plots each with an area of 0.017 ha were arranged in groups of four where a central plot is surrounded by three plots that are each at $36.6 \mathrm{~m}$ from the central plot. In each plot, all woody plants that were $\geq 10 \mathrm{~cm}$ in DBH were sampled for floristic diversity. Biodiversity analyses were accomplished using the Shannon-Weaver's Index (H') to assess the tree species diversity and Shannon Equitability (H'E) was calculated to assess the evenness values of species while the Importance Value Index (IVI) of each woody species was analyzed to see the Importance of individual tree and shrub species at the site. A total of 65 trees and shrub species belonging to 38 families had been recorded in this study. Rosaceae was a family with the highest number of species comprising about $9.23 \%$ of the total number of species. The $H^{\prime}$ ranged between 0.004 to 0.362 with the overall $H^{\prime}$ of 2.82 . The H'E values ranged between 0.001 to 0.087 with a mean value of 0.01 . A mean H'E value of 0.01 indicates that the relative homogeneity of woody plant species of the sampled plots was $1 \%$ of the maximum possible even population. The evenness values are not enough to justify uniformity in composition of tree species. The mean IVI value ranged between 0.36 to 49.06 with mean IVI value of 6.0 . In this study only $15 \%$ of the recorded species were found with IVI values $>10$ and the rest of $85 \%$ have IVI values $<10$. The variation in survival mechanisms of species made some species to be dominant and most species to be lower in number in a given ecosystem. Tree species with high IVI were also found to have higher $H^{\prime}$ of diversity. The spatial distribution and dominance of species can be affected both by the properties of the species themselves and the environmental factors. The diversity of woody species observed in the Ades dry afromontane is encouraging since, among other reasons, it is useful for conservation strategy.
\end{abstract}

Keywords: Shannon-Weaver, Evenness, Trees, Shrubs, Sampling Design, Important Value Index, DBH

\section{Introduction}

Dense and Extensive forest resources were once covered the highland area of Ethiopia [13]. Today these extensive forest resources of the country are under threats of deforestation and forest degradation. The rate of deforestation in Ethiopia has been estimated to be between 150,000 ha and 200,000 ha [12].

The continuous deforestation and degradation of forest ecosystems in Ethiopia in general and in Ades dry afromontane forest in particular, is of major concern due to the negative impacts this has on many of the ecosystem service. The Ades dry afromontane forest, which is characterized by a variety of tree species have lost its cover due to agricultural land expansion and illegal logging activities. This degradation has affected the plant species composition and presented threats for some of the tree species.

In recognition to the above listed threats to forest biodiversity, the government of Oromia National Regional State has designed the establishment of Participatory Forest Management (PFM) as one of various strategies for 
conservation of forest resources through solving the problem of open access to the forest resource and promoting sustainable forest management. Because of lack of awareness on the principles of PFM by the members of PFM living in and/or near by the forest, still there exist exploitation of the forest resource through illegal logging, cutting for fuel wood and expansion of agricultural lands. Information with regard to the diversity, composition and importance values of woody plant species in the forest is necessary for conservation and sustainable utilization of the forest resources.

This study was therefore aimed to assess the floristic composition and diversity and to analyze important value index of woody species in Ades dry afromontane forest by exploring the identity and variety of woody species that have regenerated within the forest.

\section{Materials and Methods}

\subsection{Description of the Study Site}

The study was conducted in Ades dry afromontane forest located between $1029419 \mathrm{~m} \mathrm{E}$ to $1030017 \mathrm{~m} \mathrm{E}$ and $746685 \mathrm{~m}$ $\mathrm{N}$ to $746986 \mathrm{~m} \mathrm{~N}$. It is about $407 \mathrm{~km}$ to East of Addis Ababa, in Oromia National Regional State, Southeastern Ethiopia (Figure 1). The forest covers a total area of 618 ha and its altitude ranges from $2517 \mathrm{~m}$ to $2743 \mathrm{~m}$ a.s. 1 . The weather condition of the study area is characterized by coldest climate which is locally known as 'Baddaa' in Afan Oromo language. The mean annual temperature ranges between $17^{\circ} \mathrm{C}$ and $24{ }^{0} \mathrm{C}$ and the mean annual rainfall ranges between $600 \mathrm{~mm}$ to $1250 \mathrm{~mm}$ [18]. Its rain fall distribution is mostly from July to September. The dry and hot season is mostly starts from the middle of December to the end of March.

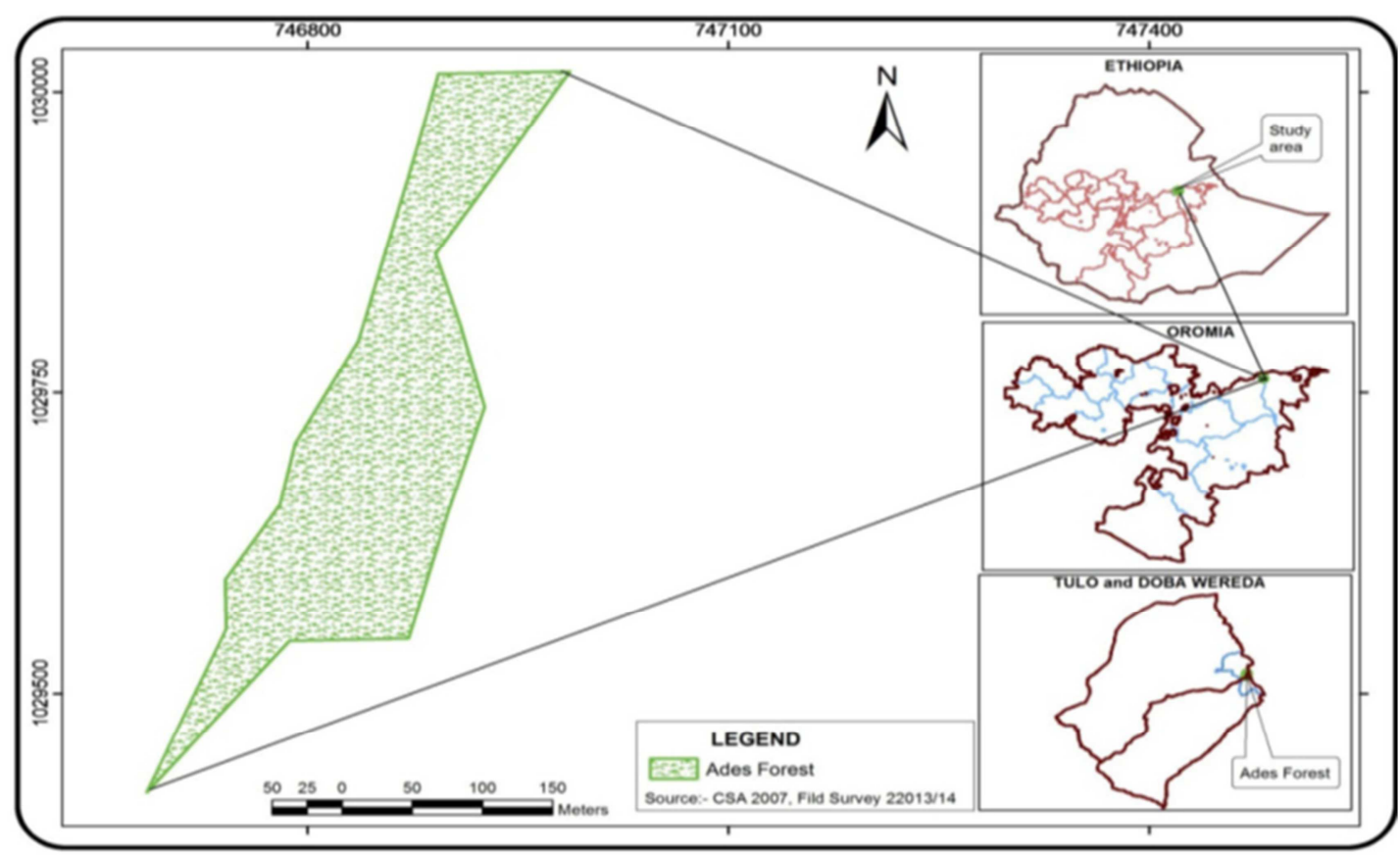

Figure 1. Map of the study area.

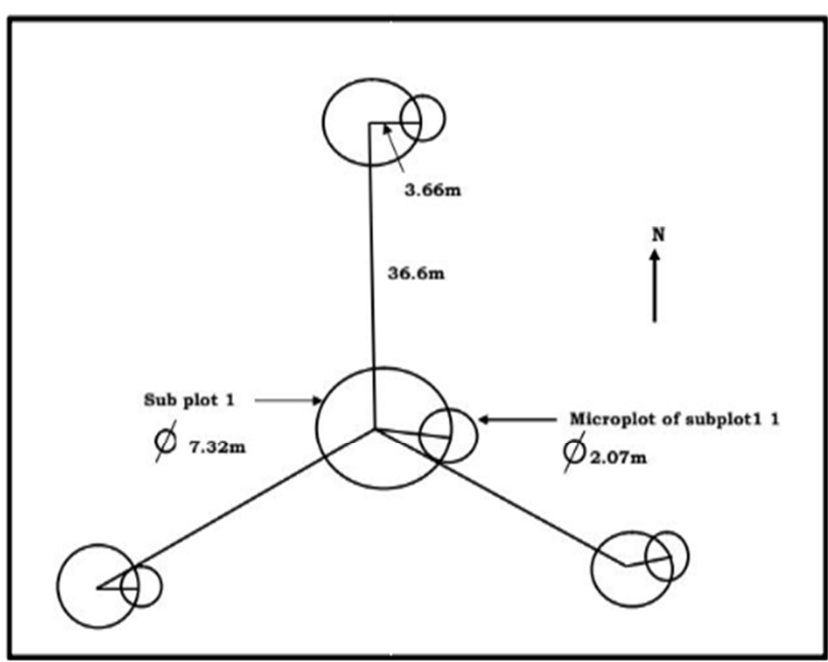

Figure 2. Layout of plots and sub-plots.

\subsection{Methods}

\subsubsection{Sampling Design}

The layout of the plots for the assessments of woody species diversity was adopted from design developed for The Forest Inventory and Analysis Programme (FIA) [29]. A circular plots each with an area of 0.017 ha arranged in groups of four where a central plot is surrounded by three plots to form an equilateral triangle at a distance of $36.6 \mathrm{~m}$ out from the central plot to each of the three surrounding plots were laid out (Figure 2). Pairs of plots were established and two plots had been selected at random from each group of plots, and totally of 60 plots from 30 groups were sampled in this study.

\subsubsection{Measurement of Woody Vegetation}

Counting the number of stems and measurement of diameter at breast height (DBH) in each plot were conducted 
for each of the woody plant species. The DBH of all living woody stems (trees and shrubs $\geq 10 \mathrm{~cm} \mathrm{DBH}$ ) was measured using Caliper and a $5 \mathrm{~m}$ diameter tape. The identification of species was made using a guide book Flora of Ethiopia and Eritrea [14], with the assistance of a local Para-taxonomist. For those species difficult to identify in the field, fresh specimens were collected and taken to the National Herbarium of Addis Ababa University for identification.

\subsubsection{Data Analysis}

i Species diversity: The Shannon-Weaver's index ( $\left.\mathrm{H}^{\prime}\right)$ was used as measure of diversity [20] and calculated as $\mathrm{H}^{1}=-\Sigma P i \ln P i$ where: $i$, is the proportion of the species relative to the total number of species $\left(\mathrm{p}_{i}\right)$ and $\ln$ is a natural logarithm.

ii Species richness $(S)$ : Species richness as the number of species present in an ecosystem was calculated as: $S=\Sigma n$ Where: $n$ is number of species.

iii Species evenness (H'E): Species evenness was assessed by Shannon's equitability index calculated as: $\mathrm{H}^{\prime} \mathrm{E}=$ $\mathrm{H}^{\prime} / \mathrm{H}_{\max }$ Where: $\mathrm{H}_{\max }$ is defined as $\ln \mathrm{S}$

iv The Importance Value Index (IVI): The index was calculated by integrating: The Relative frequency (RF); Relative density (RD) and Relative Dominance (RB) of species $[15,25]$. It is calculated as: $\mathrm{IVI}=(\mathrm{RF}+\mathrm{RD}+\mathrm{RB})$

\section{Results and Discussion}

\subsection{Floristic Composition}

A total of 65 tree and shrub species belonging to 38 families (Table 1) were identified, out of these trees constituted $67.7 \%$ while shrubs were $32.3 \%$. Sixteen families each with more than one species comprise $66.2 \%$ of the total number of species recorded in the study area and the rest of 22 families each were represent only by one species (Table 2). Rosaceae comprise the highest number of species (6) followed by Oleaceae and Myrsinaceae (4 species each), Flacourtiaceae, Celastraceae, and Asteraceae (3 species each), Ulmaceae, Rubiaceae, Polygonacea, Myrtaceae, Meliaceae, Fabaceae, Euphorbiaceae, Cupressaceae, Boraginaceae, and Araliaceae (2 species each). Habitat adaptation and favorable environmental conditions could encourage the prevalence of Rosaceae family [7, 30]. The influence of edaphic parameter (soil nutrients) in species richness and establishment in an ecosystem was also supported by other studies [28, 3$]$.

Species that are at low level in some parts of Ethiopia such as: Juniperus procera, Hagenia abyssinica, and Podocarpus falcatus, are highly found in Ades dry Afromontane forest. This could be due to the establishment of Participatory Forest Management where the local communities are engaged in forest protection and management.

Table 1. Lists of trees and shrub species in Ades dry afromontane forest, South Eastern Ethiopia.

\begin{tabular}{|c|c|c|c|c|c|}
\hline Family & Species & Life form & Family & Species & Life form \\
\hline Anacardiaceae & Rhus glutinosa & Shrub & \multirow{2}{*}{ Myrsinaceae } & Myrsine africana & Tree \\
\hline Apocynaceae & Carrisa edulis & Shrub & & Rapanea simensis & Tree \\
\hline \multirow{2}{*}{ Araliaceae } & Polyscias fulva & Tree & Myrtaceae & Sizygeem guineense & Tree \\
\hline & Schfflera abyssinica & Tree & \multirow{4}{*}{ Oleaceae } & Jasminum abyssinicum & Tree \\
\hline \multirow{3}{*}{ Asteraceae } & Vernonia amygdalina & Tree & & Olea europaea & Tree \\
\hline & Vernonia auriculifera & Shrub & & Olea capensis & Tree \\
\hline & Vernonia leopoldii & Shrub & & Olinia rochetiana & Shrub \\
\hline Balanitaceae & Balanytus aegyptica & Tree & Papilonaceae & Erythrina brucei & Tree \\
\hline \multirow{2}{*}{ Boraginaceae } & Cordia africana & Tree & Phytolacaceae & Phytolacca dedocandra & Shrub \\
\hline & Ehretia cymosa & Tree & Pittosporaceae & Pittosporum abyssinicum & Tree \\
\hline \multirow[b]{2}{*}{ Celastraceae } & Chata edulis & Shrub & Podocarpaceae & Podocarpus falcatus & Tree \\
\hline & Maytenus arbutifolia & Tree & Polygonacea & Rumex abyssinicus & Shrub \\
\hline \multirow{2}{*}{ Cupressaceae } & Cuprecess lusitanica & Tree & Proteaceae & Gravelea robusta & Tree \\
\hline & Juniperus procera & Tree & Rhamnaceae & Rhamnus prenoids & Shrub \\
\hline \multirow{2}{*}{ Euphorbiaceae } & Croton macrostachys & Tree & \multirow{6}{*}{ Rosaceae } & Hagenia abyssinica & Tree \\
\hline & Macaranga kilimandsharica & Tree & & Prunus africana & Tree \\
\hline \multirow{2}{*}{ Fabaceae } & Calpunia subdecandra & Shrub & & Rosa abyssinica & Shrub \\
\hline & Calpurina aura & Shrub & & Rosmarinus offinalis & Tree \\
\hline & Dovyalis caffra & Shrub & & Rubus apetalus & Tree \\
\hline Flacourtiaceae & Dovyalis abyssinica & Shrub & & Rubus studneri & Tree \\
\hline \multirow{3}{*}{$\begin{array}{l}\text { Hypericaceae } \\
\text { Icacinaceae }\end{array}$} & Dovyalis vericosa & Shrub & \multirow{2}{*}{ Rubiaceae } & Gardenia lutea & Tree \\
\hline & Hypercum revolutum & Shrub & & Rytigynia neglecta & Shrub \\
\hline & Apodytes dimidiata & Tree & Sapindaceae & Dodonaea angustifolia & Tree \\
\hline Lamiacae & Ocimum lamifolium & Shrub & Sapotaceae & Aningeria altissima & Tree \\
\hline Lauraceae & Ocotea kenyensis & Tree & Simaroubaceae & Brucea antidysenterica & Shrub \\
\hline
\end{tabular}




\begin{tabular}{llllll}
\hline Family & Species & Life form & Family & Species & Life form \\
\hline Melianthaceae & Barsama abyssinica & Tree & Ulmaceae & Celtis africana & Tree \\
Moraceae & Ficus sur & Tree & & Clerodendron myricoides & Shrub \\
\multirow{2}{*}{ Myrsinaceae } & Embelia schimpri & Tree & Verbenaceae & Premna schimperi & Tree \\
& Maesa lanceolata & Tree & & & \\
\hline
\end{tabular}

This finding was not in line with the works from Forest of Assam on vegetative assessment of tree species and shrubs where Moraceae, Meliaceae and Papilionaceae have been represented with more number of species due to their ability to produce numerous seeds which was eventually establish at suitable sites [10]. But in this study, they were represented only by one species. This may be due to the geographic variations of the two study sites and the result of this study was in line with the study conducted on tropical forests regeneration and survival of tree seedlings [17].

The number of plant species (65) recorded in Ades dry afromontane forest was higher as compared with some studies conducted in Ethiopia [1, 27, 32, 6] and elsewhere in tropical areas from Tungnath [22]. This may be due to geographic differences and variations in vegetation formation of these study sites. However, this figure is lower when compared to the number of species recorded in Jello-Muktar dry afromontane forest under similar agro-ecology from Eastern Ethiopia [24]. Similarly, the number of plant species recorded in this study were lower when compared to the number of species recorded for forests of other ago-ecologies in Ethiopia [5, 33, 23] and some tropical countries [7, 8].

The reasons for those 22 families in the present study represented each only by one species or the poor number of species observed in these families could be attributed to diseases and browsing by herbivores which resulted in poor growth and establishment and perhaps seeds need scarification treatment before germination as study conducted on seedling populations and regeneration of woody species in dry Afromontane forests of Ethiopia [11]. The low number of species could also be attributed to anthropogenic activities which affected species growth and production [9].

Table 2. Plant Families with their number of woody plant species occurred in Ades dry afromontane forest, South Eastern Ethiopia.

\begin{tabular}{|c|c|c|c|c|c|}
\hline Family & Species number & $\%$ & Family & Species number & $\%$ \\
\hline Anacardiaceae & 1 & 1.54 & Myrsinaceae & 4 & 6.15 \\
\hline Apocynaceae & 1 & 1.54 & Myrtaceae & 2 & 3.08 \\
\hline Aquifoliaceae & 1 & 1.54 & Oleaceae & 4 & 6.15 \\
\hline Araliaceae & 2 & 3.08 & Papilonaceae & 1 & 1.54 \\
\hline Asteraceae & 3 & 4.62 & Phytolacaceae & 1 & 1.54 \\
\hline Balanitaceae & 1 & 1.54 & Pittosporaceae & 1 & 1.54 \\
\hline Boraginaceae & 2 & 3.08 & Podocarpaceae & 1 & 1.54 \\
\hline Celastraceae & 3 & 4.62 & Polygonacea & 2 & 3.08 \\
\hline Cupressaceae & 2 & 3.08 & Proteaceae & 1 & 1.54 \\
\hline Euphorbiaceae & 2 & 3.08 & Rhamnaceae & 1 & 1.54 \\
\hline Fabaceae & 2 & 3.08 & Rosaceae & 6 & 9.23 \\
\hline Flacourtiaceae & 3 & 4.62 & Rubiaceae & 2 & 3.08 \\
\hline Hypericaceae & 1 & 1.54 & Sapindaceae & 1 & 1.54 \\
\hline Lamiacae & 1 & 1.54 & Simaroubaceae & 1 & 1.54 \\
\hline Lauraceae & 2 & 1.54 & Solanaceae & 1 & 1.54 \\
\hline Meliaceae & 1 & 3.08 & Sterculiaceae & 1 & 1.54 \\
\hline Melianthaceae & 1 & 1.54 & Ulmaceae & 2 & 3.08 \\
\hline Moraceae & 1 & 1.54 & Verbenaceae & 1 & 1.54 \\
\hline
\end{tabular}

The number of trees and shrub species in the present study, about $95 \%$ of which are indigenous to the area, indicates the significant role of the forest in conservation of biological diversityas reported from studies elsewhere in East Usambara Forest Reserves [16]. The high number of species richness in the study area is again attributed to the current protection measures given to the forest that via allows the regeneration of different species from soil seed bank. Some economic activities particularly, beekeeping through participatory forest management is highly encouraged in Ades dry afromontane forest by the presence of such floristic diversity.

\subsection{Pattern of Distribution of Woody Species in Plant Families by Their Life Forms}

With regard to the pattern of distribution of the number of woody species by life forms in each family, Rosaceae again comprise the highest number of tree species (5) and followed by Myrsinaceae (4) and Oleaceae (3) and the rest twelve families comprise each 2 tree species while 6 families were represented only by 1 tree species (Figure 3 ).

The distribution of shrub species in each family ranges between 1 to 3 where Flacourtiaceae comprise the highest number of shrub species (3) followed by Asteraceae, 
Fabaceae and Polygonacea ( each with 2 shrub species) and the rest 12 families were represented only by one shrub

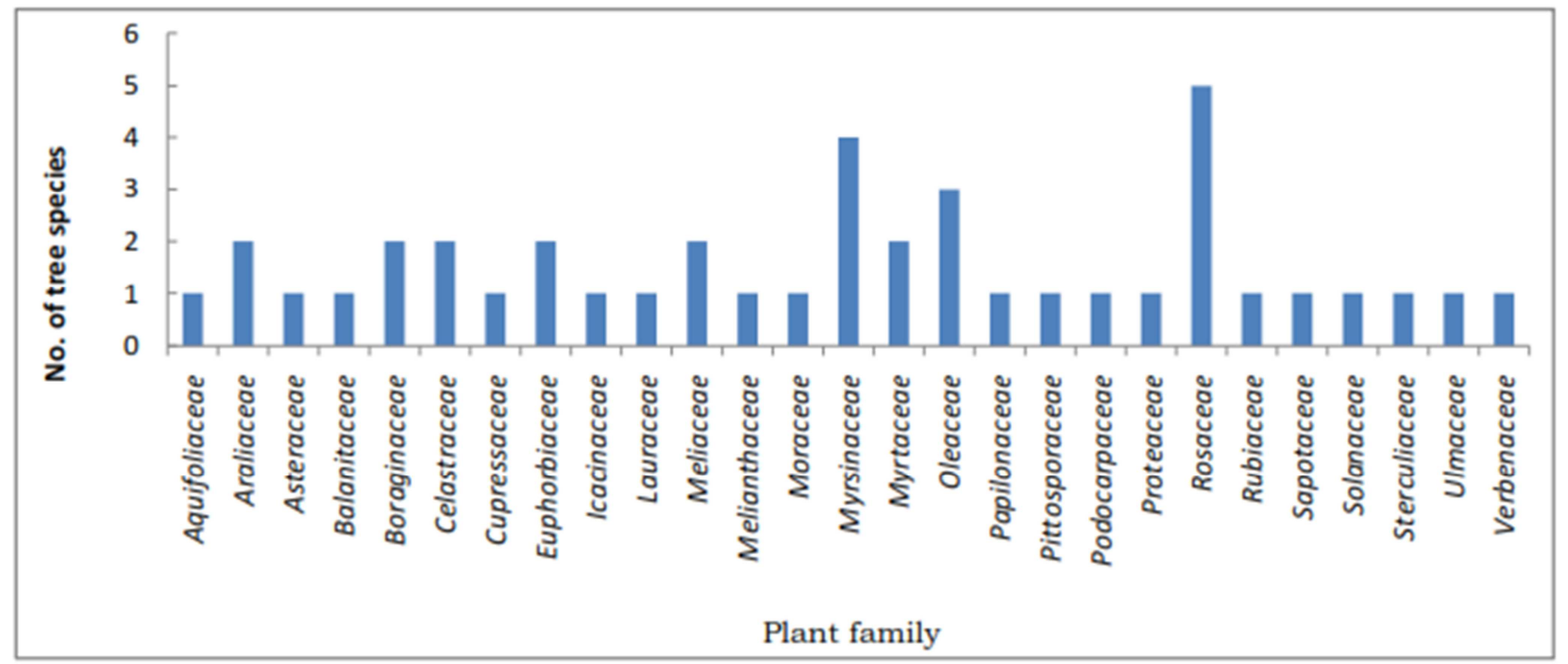

Figure 3. Distribution of tree species in the plant families.

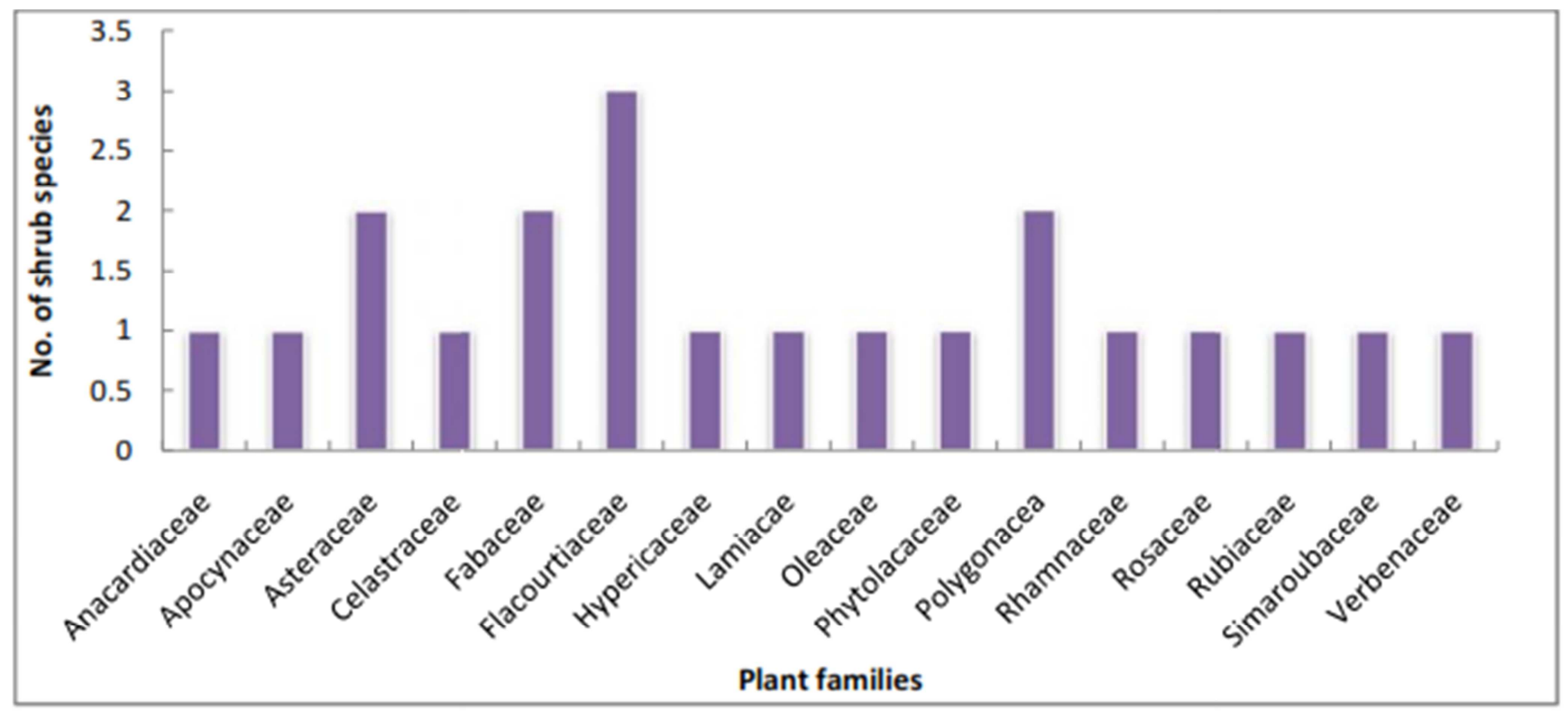

Figure 4. Distribution of Shrub species in plant families.

\subsection{Species Diversity and Evenness}

The Shannon index of diversity for tree and shrub species in this study ranged between 0.004 to 0.3623 with the overall $H^{\prime}$ of 2.82 (Table 3 ). Species noted to have contributed to high Shannon index of diversity include: Podocarpus falcatus (0.3623), Eucalyptus globules (0.2290), Juniperus procera (0.2120), Croton macrostachys (0.074), Cordia africana (0.066), Ficus sur (0.063), Cuprecess lusitanica (0.063), Embelia schimpri (0.059), Hagenia abyssinica (0.054), Ekebergia capensis ( 0.053), Ehretia cymosa (0.050), Hypercum revolutum and Carrisa edulis (each 0.047), Myrsine africana, Maytenus obscura and Barsama abyssinica ( each 0.042) (Table 3). The overall H' of these species accounts about $50 \%$ of the total H' for all species recorded in the study site. Species of Sizygeem guineense, Celtis africana, Rosmarinus offinalis, Rubus apetalus and Rubus studneri were among tree and shrub species with the lowest Shannon index of diversity. The Shannon index of diversity recorded for Podocarpus falcatus (0.3623) was again higher than the overall $\mathrm{H}^{\prime}$ of the first eighteen trees and shrub species with lowest H'. Podocarpus falcatus with the highest Shannon index of diversity in this study also showed the highest IVI. 
Table 3. Tree and shrub species diversity indices at Ades dry afromontane forest, South Eastern Ethiopia.

\begin{tabular}{|c|c|c|c|c|c|}
\hline Species & $\mathbf{H}^{\prime}$ & H'E & Species & $\mathbf{H}^{\prime}$ & H'E \\
\hline Aningeria altissima & 0.041 & 0.01 & Macaranga kilimandsharica & 0.039 & 0.009 \\
\hline Apodytes dimidiata & 0.036 & 0.009 & Maesa lanceolata & 0.041 & 0.01 \\
\hline Balanytus aegyptica & 0.023 & 0.006 & Maytenus arbutifolia & 0.037 & 0.009 \\
\hline Barsama abyssinica & 0.042 & 0.01 & Maytenus obscura & 0.042 & 0.01 \\
\hline Brucea antidysenterica & 0.034 & 0.008 & Myrsine africana & 0.042 & 0.01 \\
\hline Calpunia subdecandra & 0.035 & 0.008 & Ocimum lamifolium & 0.031 & 0.008 \\
\hline Cuprecess lusitanica & 0.063 & 0.015 & Olea europaea & 0.041 & 0.01 \\
\hline Calpurina aura & 0.041 & 0.01 & Olea capensis & 0.035 & 0.008 \\
\hline Celtis africana & 0.014 & 0.003 & Olinia rochetiana & 0.041 & 0.01 \\
\hline Chata edulis & 0.03 & 0.007 & Phytolacca dedocandra & 0.022 & 0.005 \\
\hline Clerodendron myricoides & 0.021 & 0.005 & Pittosporum abyssinicum & 0.037 & 0.009 \\
\hline Croton macrostachys & 0.074 & 0.018 & Podocarpus falcatus & 0.362 & 0.087 \\
\hline Cordia africana & 0.066 & 0.016 & Polyscias fulva & 0.024 & 0.006 \\
\hline Dodonaea angustifolia & 0.027 & 0.007 & Premna schimperi & 0.035 & 0.008 \\
\hline Dombeya torrida & 0.027 & 0.007 & Rapanea simensis & 0.024 & 0.006 \\
\hline Dovyalis caffra & 0.036 & 0.009 & Rhamnus prenoids & 0.031 & 0.008 \\
\hline Dovyalis abyssinica & 0.025 & 0.006 & Rhus glutinosa & 0.021 & 0.005 \\
\hline Dovyalis vericosa & 0.023 & 0.006 & Rosa abyssinica & 0.022 & 0.005 \\
\hline Erythrina brucei & 0.025 & 0.006 & Rosmarinus offinalis & 0.016 & 0.004 \\
\hline Ehretia cymosa & 0.05 & 0.012 & Rubus apetalus & 0.016 & 0.004 \\
\hline Ekebergia capensis & 0.053 & 0.013 & Rubus studneri & 0.017 & 0.004 \\
\hline Embelia schimpri & 0.059 & 0.014 & Rumex abyssinicus & 0.02 & 0.005 \\
\hline Eucalyptus globulus & 0.229 & 0.055 & Rumex nurvosus & 0.018 & 0.004 \\
\hline Ficus sur & 0.063 & 0.015 & Rytigynia neglecta & 0.02 & 0.005 \\
\hline Gardenia lutea & 0.038 & 0.009 & Schfflera abyssinica & 0.023 & 0.006 \\
\hline Gravelea robusta & 0.033 & 0.008 & Sizygeem guineense & 0.004 & 0.001 \\
\hline Ilex mitis & 0.041 & 0.01 & Vernonia leopoldii & 0.025 & 0.006 \\
\hline Jasminum abyssinicum & 0.023 & 0.006 & & & \\
\hline Juniperus procera & 0.111 & 0.026 & & & \\
\hline Lepidotrichilia volkensis & 0.021 & 0.005 & & & \\
\hline
\end{tabular}

The study revealed Shannon-Wiener Index of diversity ( $\left.\mathrm{H}^{\prime}\right)$ of 2.82 for the Ades dry Afromontane forest (Table 3). This index tells about species richness (number of species) and evenness (species distribution) [21]. The larger the value of $\mathrm{H}^{\prime}$ the greater the species diversity and vice versa. An ecosystem with $\mathrm{H}^{\prime}$ value greater than 2 has been regarded as medium to high diverse in terms of species [4]. Arich ecosystem having high species diversity has also a larger value of Shannon index of diversity and vise-versa [10]. The Ades dry afromontane forest is thus belongs to an area with high species diversity.

The Shannon index of diversity recorded in this study was higher than those studies conducted for some other forests types $[31,26]$. The sizes of trees enumerated in those studies (i.e., within minimum DBH set at $12.7 \mathrm{~cm}$ as opposed to $10 \mathrm{~cm}$ in this study) could be among the factors for the observed differences in terms of Shannon index of diversity between the two sites. The high diversity of tree species observed in the Ades dry Afromontane is encouraging since, among other reasons, it is useful for conservation purposes.
The evenness values for tree species of the present study ranged between 0.001 to 0.087 with a mean value of 0.01 and overall evenness value of 0.67 (Table 3). A mean evenness value of 0.01 indicates that the relative homogeneity of tree species of the sampled forest plots was $1 \%$ of the maximum possible even population. The evenness values are not enough to justify uniformity in composition of tree species. This is expected because not all trees are equally distributed and there is some variation in the distribution of species in the study area. Tree species that showed higher evenness values were Podocarpus falcatus (0.087), Eucalyptus globules (0.055), Juniperus procera (0.026), Croton macrostachys (0.018), Cordia africana (0.016), Cuprecess lusitanica and Ficus sur (each 0.015) and Embelia schimpri (0.015). These species also showed higher Shannon index of diversity (Table 3 ). The evenness value of tree with the highest index (Podocarpus falcatus) was about 87 times higher than the tree species with the lowest evenness value (Sizygeem guineense). This was supported by study conducted on Masha forest where the lower evenness values in forest indicate the dominance of a few species [2]. In this 
study, a high evenness values for indigenous species indicates that little dominance by any single species but repeated co-existence of species over all plots in the forest as reported for some species in Northeastern Ethiopia [2]. The evenness values recorded in this study are lower than the eveness values reported from Western Kenya that ranged between 0.24 to 0.71 [19] .

\subsection{Importance Value Index (IVI)}

In all sample plots assessed Podocarpus falcatus ranked first with mean IVI of 49.06, followed by Juniperus procera (34.15), Eucalyptus globules (30.6), Cuprecess lusitanica (23), Olea europeana (20.17), Hagenia abyissinica (14.69), Vernonia auriculifera (13.32) and Croton macrostachys (12.25) (Table 4). Contrary to this, Sizygeem guineense, Rytigynia neglecta, Rosmarinus offinalis, Rubus apetalus, Balanytus aegyptica, Rumex abyssinicus were the species with the lowest IVI. The mean IVI of Hagenia abyssinica was higher than those tree species which were officially declared endangered at the national level in Ethiopia next to Junipurus procera. Most of the tree species with higher IVI were indigenous although Eucalyptus globules and
Cuprecess lusitanica species ranked first and second among species of exotic plantations.

The mean IVI value in this study ranged between 0.36 to 49.06 with mean IVI value of 6.0. It has been reported that IVI value of tree species in stands with only one species can reach a maximum of 300 [25]. In this study only $15 \%$ of the recorded species were found with IVI values $>10$ and the rest of $85 \%$ have IVI values $<10$. On the other hand the first fifteen species with higher IVI values (Table 4), accounted about $64 \%$ of the total IVI for the present study which indicates that few species are dominating the area. The variation in survival mechanisms of species made some species to be dominant and most species to be lower in number in a given ecosystem [15]. The spatial distribution and dominance of species can be affected both by the properties of the species themselves and the environmental factors [28].

These results disclose that the most important species in Ades dry afromontane forest havehigh diversity in the scale of Shannon-Weiner Index of Diversity. The IVI rank species in a way as to give an indication on which species come out as important element of the Ades dry afromontane forest trees.

Table 4. Overall Mean IVI of trees and shrub $(>10 \mathrm{~cm}$ DBH) species in Ades dry afromontane forest, South Eastern Ethiopia.

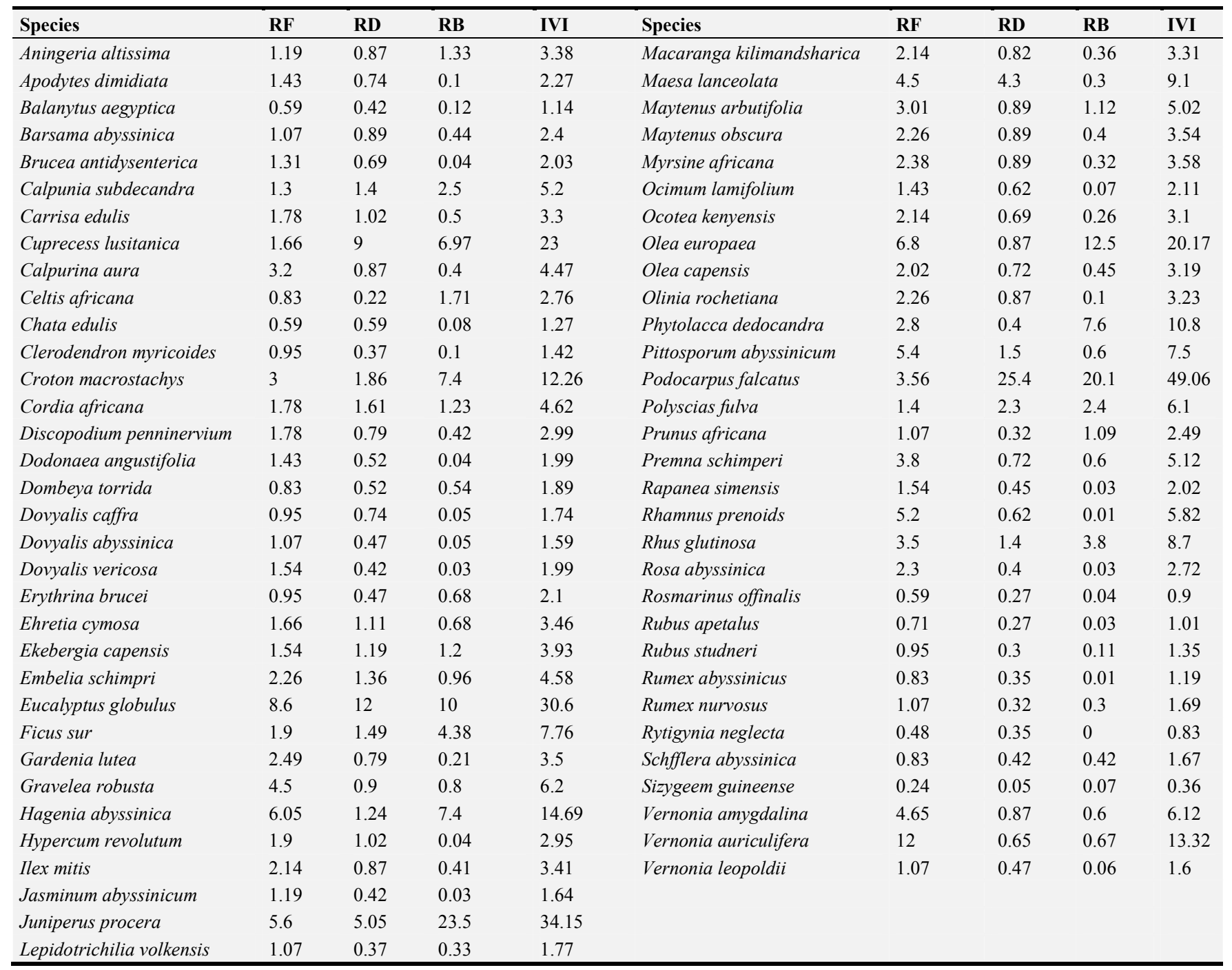




\section{Conclusion and Recommendation}

A total of 65 trees and shrub species belonging to 38 families were identified, out of these trees constituted $67.7 \%$ while shrubs were $32.3 \%$. Sixteen families each with more than one species comprise $66.2 \%$ of the total number of species recorded in the study area and the rest of 22 families each represent only one species. The Shannon index of diversity $\left(H^{\prime}\right)$ for tree and shrub species in this study ranged from 0.004 to 0.3623 with the overall $H^{\prime}$ of 2.82 and the evenness values for tree species of the present study ranged between 0.001 to 0.087 with a mean value of 0.01 and overall evenness value of 0.67 . A mean evenness value of 0.01 indicates that the relative homogeneity of tree species of the sampled forest plots was $1 \%$ of the maximum possible even population. The evenness values are not enough to justify uniformity in composition of tree species. This is expected because not all trees are equally distributed and there is some variation in the distribution of species in the study area. The mean IVI value in this study ranged between 0.36 to 49.06 with mean IVI value of 6.0 . This value is lower when compared with some studies. In this study only $15 \%$ of the recorded species were found with IVI values $>10$ and the rest of $85 \%$ have IVI values $<10$.

The high number of species richness in the study area is again attributed to the current protection measures given to the forest that via allows the regeneration of different species from soil seed bank. Some economic activitiesparticularly, beekeeping through participatory forest management is highly encouraged in Ades dry afromontane forest by the presence of such floristic diversity. Further study regarding the richness and diversity of woody species to investigate the distribution of tree species for conservation and sustainable utilization is recommended.

\section{Acknowledgements}

We would like to thank Oda Bultum University for Grant funding of this Research. We appreciate and thank Office of Forestry and Wildlife Enterprise of Oromia National Regional State, Hararghe branch for providing us car during data collection. We also thank Forestry Experts of Doba District in West Hararghe Zone Administration who were involved in data collection. Finally we thank local elders who helped us in providing the local names of plant species.

\section{References}

[1] Abera A. and Yasin A. 2018. Diversity and Abundance of Woody Plant Species of Assosa Forest Field Gene, Benishanigul Gumuz Regional State, Western Ethiopia. International Journal of Plant Biology \& Research 6(5): 1100.

[2] Abrham Abiyu, Vacik, H. and Glatzel, G. 2006. Population viability risk management applied to Boswellia papyfera (Del.) Hochst in Northeastern Ethiopia. Journal of the Dry lands 1 (2):98-107.
[3] Austin M. P. \&Heyligers P. C. 1989. Vegetation survey design for conservation: gradsect sampling of forestsin northeastern New South Wales. Biological Conservation 50:13-32.

[4] Barbour M. D., Burk J. H. \& Pitts W. D. 1987. Terrestrial plant ecology, $2^{\text {nd }}$ Edition. Benjamin Cummings Inc., Menlo Park, CA, 634p.

[5] Bekalo, T. H., S. D. Woodmatas \& Z. A. Woldemariam. 2009. An ethnobotanical study of medicinal plants used by local people in the lowlands of Konta Special Woreda, southern nations, nationalities and peoples regional state, Ethiopia. Journal of Ethnobiology and Ethnomedicine 5:26-40.

[6] Belaynah, A., Z. Asfaw, S. Demissew \& N. F. Bussa. 2012. Medicinal plants potential and use by pastoral and agropastoral communities in Erer Valley of Babile Wereda, eastern Ethiopia. Journal of Ethnobiology and Ethno medicine 8:42-64.

[7] Carlos Almazán-Núñez, R., María del Coro Arizmendi, Luis E. Eguiarte and Pablo Corcuera. 2012. Changes in composition, diversity and structure of woody plants in successional stages of tropical dry forest in southwest Mexico. Revista Mexicanade Biodiversidad 83:1096-1109.

[8] Cazzolla Gatti R, Vaglio Laurin G, Valentini R. 2017. Tree species diversity of three Ghanaian reserves. iForest 10: 362368. - doi: 10.3832/ifor2056-010 [online 2017-03-07].

[9] Chauhan DS, Dhanai CS, Bhupendra S, Chauhan S, Todaria NP, Coley PD, Barone JA. 1996. Herbivory and plant defenses in tropical forests Ann. Rev. Ecol. Syst. 27:305-335.

[10] Deka J, Tripathi PO, Khan LM. 2012. High Dominance of Shorea robusta Gaertn. in Alluvial Plain Kamrup Sal Forest of Assam, N. E. India Int. J. Ecosys. 2(4):67-73.

[11] Demel Teketay. 1997. Seedling populations and regeneration of woody species in dry Afromontane forests of Ethiopia. Forest Ecology and Management 98:149-165.

[12] EFAP. 1994. Ethiopian Forestry Action Program. (EFAP), Addis Ababa.

[13] EMA. 1988. National Atlas of Ethiopia. Ethiopian Mapping Authority, Addis Ababa.

[14] Hedberg, I., Friis, I. and Edwards, S. 2004. Flora of Ethiopia and Eritrea. The National Herbarium, Addis Ababa University, Addis Ababa and Department of Systematic Botany, ppsala University, Uppsala.

[15] Kent, M., and P. Coker. 1992. Vegetation description and analysis Belhaven Press, London.

[16] Kessy, J. F. 1998. Conservation and Utilization of Natural Resources in the East Usambara Forest Reserves: Conventional Views and Local Perspectives. PhD thesis, 168pp.

[17] Khan ML, Rai JPN, Tripathi RS. 1986. Regeneration and survival of tree seedlings and sprouts tropical deciduous and subtropical forests of Meghalaya, India. Forest Ecololgy and Management 14,293-304.

[18] Kidanemariam K., Teshome S., Satish kumar B. 2015. Forest Carbon Stock in Woody Plants of AdesForest, Western Hararghe Zone of Ethiopia and its Variation along Environmental Factors:Implication for Climate Change Mitigation. Journal of Natural SciencesResearch. Vol. 5, No. 2. 
[19] Kindt, R. Noordin, Q., Njui, A. and Ruigu, S. 2005. Biodiversity Conservation through Agroforestry:Managing Tree Species Diversity within a Net work of Communitybased Non-governmental, Governmental and Research Organizations in Western Kenya. Paper presented at $15^{\text {th }}$ Annual Conference of the Eastern Africa Environmental Network on Networking for Biodiversity, 27-28 May, National Museum of Kenya, Nairobi.

[20] Lou, J. 2006. Entropy and diversity. Oikos 113 (2): 363-375.

[21] Magurran, A. E. 1988. Ecological Diversity and its Measurement. Princeton University Press, 192pp. Princeton

[22] Malik ZA \& Nautiyal MC. 2016. Species richness and diversity along the altitudinal gradient in Tungnath, the Himalayan benchmark site of HIMADRI. Tropical Plant Research 3(2): 396-407.

[23] Mesfin Woldearegay, Zerihun Woldu and Ermias Lulekal. 2018. Species diversity, population structure and regeneration status of woody plants in Yegof dry afromontane forest, Northeastern Ethiopia. European Journal of Advanced Research in Biological and Life Sciences. Vol. 6 No. 4. ISSN 2056-5984.

[24] Muktar Reshad, Muktar Mohammed, Ahmed Mohammed and Alemayehu Beyene. 2017. Diversity of Non-Timber Forest Products (NTFPs) and its Source Plant Species: The Case of Jello-Muktar Forest, Eastern Ethiopia.

[25] Muller-Dombois, D., H. Ellenberg. 1974. Aims and methods of vegetation ecology. John Willey and Sons, New York. Region of Wisconsin. Ecology 32: 476-496.

[26] Rogers, P. C. \& Ryel, R. J. 2008. Lichen community change in response to succession in aspenforests of the Rocky
Mountains, USA. Forest Ecology and Management, 256: $1760-1770$

[27] Shiferaw W, Lemenih M \& Gole TWM. 2018. Analysis of plant species diversity and forest structure in Arero dry Afromontane forest of Borena zone, South Ethiopia Tropical Plant Research 5(2): 129-140.

[28] Solbrig, O. T., E. Medina, and J. F. Silva. 1996. Biodiversity and Savana ecosystem process: A Prespective Springer-Verlag Berlin Hedelberg, Berlin.

[29] United States Department of Agriculture Forest Service. 2007. Field methods instructions for Phase 2 (Forest Inventory) and Phase 3 (Forest Health) of the National Forest Inventory and Analysis program.

[30] Wassie, A. \& Teketay, D. 2005. Soil seed banks in Northern Ethiopia: implications for the conservation ofwoodyplants. Flora 201:32-43.

[31] Wilder, C., Brooks, T. \& Lens, L. 1998. Vegetation structure and composition of the Taita Hills forest. Journal of East African Natural History 87:181-187.

[32] Yineger, H., D. Yewhalaw \& D. Teketay. 2008. Ethno medicinal plant knowledge and practices of the Oromo ethnic group in southwestern Ethiopia. Journal of Ethnobiology and Ethnomedicine 4:11.dx. doi.org/10.1186/1746-42694-11.

[33] Zerihun Girma, George Chuyong, Paul Evangelista, and Yosef Mamo. 2018. Vascular Plant Species Composition, Relative Abundance, Distribution, and Threats in Arsi Mountains National Park, Ethiopia. Mountain Research and Development 38(2): 143-152. 